\title{
Chronic Myelomonocytic Leukemia-0
}

National Cancer Institute

\section{Source}

National Cancer Institute. Chronic Myelomonocytic Leukemia-O. NCI Thesaurus. Code C130035.

A chronic myelomonocytic leukemia characterized by the presence of less than 5 percent blasts in the bone marrow and less than 2 percent blasts in the peripheral blood. 